\title{
Prevalence of $m c r-1$ in commensal Escherichia coli from French livestock, 2007 to 2014
}

A Perrin-Guyomard ${ }^{1}$, M Bruneau $^{1}$, P Houée $^{1}, K_{\text {K Deleurme }}{ }^{1}$, P Legrandois $^{1}$, C Poirier $^{1}$, C Soumet $^{1}$, P Sanders $^{1}$

1. ANSES, Laboratoire de Fougères, Fougères, France

Correspondence: Agnès Perrin-Guyomard (agnes.perrin-guyomard@anses.fr)

Citation style for this article:

Perrin-Guyomard A, Bruneau M, Houée P, Deleurme K, Legrandois P, Poirier C, Soumet C, Sanders P. Prevalence of mcr-1 in commensal Escherichia coli from French livestock, 2007 to 2014. Euro Surveill. 2016;21(6):pii=30135. DOI: http://dx.doi.org/10.2807/1560-7917.ES.2016.21.6.30135

Colistin resistance was investigated in 1,696 isolates collected from 2007 to 2014 within the frame of the French livestock antimicrobial resistance surveillance programme. The $m c r-1$ gene was detected in all commensal Escherichia coli isolates with a minimum inhibitory concentration to colistin above the $2 \mathrm{mg} / \mathrm{L}$ cut-off value $(n=23)$. In poultry, mcr-1 prevalence was $5.9 \%$ in turkeys and $1.8 \%$ in broilers in 2014 . In pigs, investigated in 2013, this prevalence did not exceed $0.5 \%$. These findings support that $m c r-1$ has spread in French livestock.

We report mcr-1 prevalence data in commensal Escherichia coli isolated from French livestock from 2007 to 2014 .

\section{Laboratory investigation}

According to the European Union surveillance programme on antimicrobial resistance in zoonotic and commensal bacteria (directive 2003/99/EC) [1], a random sample of faecal (until 2013) or caecal (since 2014) content from the same epidemiological unit (defined as in [2]) of broilers, pigs and turkeys was taken at slaughter houses all over the country, in order to be representative of national productions. The sampling was proportional to the slaughter houses' annual throughputs and was spread over the year. The number of samples collected per animal species and year was calculated to be able to recover at least $170 \mathrm{E}$. coli isolates for each combination of bacterial species and animal production. Isolates were streaked on MacConkey medium, identified and tested for antimicrobial susceptibility by the broth microdilution method (Trek diagnostic systems) using a panel of 14 antimicrobial substances. The minimum inhibitory concentrations (MIC) obtained were compared with the epidemiological cut-off values of the European Committee on Antimicrobial Susceptibility Testing (EUCAST) [3]. The DNA of strains with a colistin MIC over $2 \mathrm{mg} / \mathrm{L}$ was extracted and the presence of $\mathrm{mcr}^{-1}$ sought by polymerase chain reaction (PCR) [4].

\section{Colistin resistance and presence of the $m r c$ - 1 gene in isolates}

Most $(1,427 / 1,450 ; 98 \%)$ commensal $E$. coli strains isolated and tested from French livestock between 2007 and 2014 were susceptible to colistin (Table).

During the study period however, a total of 23 isolates were resistant to colistin at concentrations above the cut-off value of $2 \mathrm{mg} / \mathrm{L}$, with MICs ranging from 4 to 16 $\mathrm{mg} / \mathrm{L}$. Interestingly, each individual $E$. coli isolate from French livestock with a MIC to colistin greater than the cut-off harboured the $m c r-1$ gene. From 2011 to 2013, two strains resistant to colistin were isolated from healthy pigs. The prevalence of colistin resistance in broilers was $1.8 \%$ in 2014 . In turkey production, monitoring commensal E. coli became mandatory at European level in 2014 and the prevalence of resistance to colistin was $5.9 \%$ that year. Co-resistance patterns were diverse, ranging from one to eight associated mechanism of resistance (data not shown). Nevertheless, in four of the $14 \mathrm{mcr}-1$ positive turkey isolates, colistin resistance coincided with simultaneous resistance to ampicillin, quinolones, sulfamethoxazole, tetracycline and trimethoprim (data not shown). One single strain derived from turkeys was also resistant to cefotaxime and carrying the bla $a_{\text {смY-2 }}$ gene. Plasmid profiling in order to assess the transferability of these $\mathrm{mcr}-1$ genes from food producing animals to other hosts such as humans is under progress.

\section{Discussion}

For decades, colistin has been widely used in veterinary medicine against infections caused by Enterobacteriaceae in food-producing animals in Europe [5]. To offset limited data on colistin resistance in European livestock, this antibiotic was added in 2014 to the antimicrobial substances required to be tested under antimicrobial resistance programmes conducted by European Member States (decision 2013/652/EU [2]). 
TABLE

Colistin resistant and mcr-1 positive commensal Escherichia coli strains from French livestock, France, 2007-2014

\begin{tabular}{|c|c|c|c|c|c|}
\hline Year & Animals & $\begin{array}{l}\text { E. coli strains } \\
\text { tested for MIC } \\
\text { N }\end{array}$ & $\begin{array}{l}\text { E. coli strains } \\
\text { resistant to colistin } \\
\mathbf{N}_{\mathbf{N}}\end{array}$ & $\begin{array}{l}\text { Proportion of } m c r-1 \text { positive }(\mathbf{n}) \text { among } \\
\text { colistin-resistant } E \text {. coli strains }(\mathrm{N}) \\
\mathrm{n} / \mathrm{N}\end{array}$ & $\begin{array}{l}\text { Prevalence of } m c r-1 \text { positive } E \text {. } \\
\text { coli strains } \\
\%(95 \% \mathrm{Cl})\end{array}$ \\
\hline \multirow{2}{*}{2014} & Turkeys & 239 & 14 & $14 / 14$ & $5.9(2.9-8.8)$ \\
\hline & Broilers & 227 & 4 & $4 / 4$ & $1.8(0.1-3.5)$ \\
\hline \multirow{2}{*}{2013} & Pigs & 196 & 1 & $1 / 1$ & $0.5(0.0-1.5)$ \\
\hline & Broiler & 193 & 3 & $3 / 3$ & $1.6(0.0-3.3)$ \\
\hline \multirow{2}{*}{2012} & Pigs & 194 & 0 & N.a. & N.a. \\
\hline & Broiler & 201 & 0 & N.a. & N.a. \\
\hline 2011 & Pigs & 200 & 1 & $1 / 1$ & $0.5(0.0-1.5)$ \\
\hline 2007 & Turkeys & $N D^{a}$ & $N D^{\mathrm{a}}$ & $0 / 246^{a}$ & $0(0.0-1.2)$ \\
\hline Total & All & 1,450 & 23 & N.a. ${ }^{a}$ & N.a. ${ }^{a}$ \\
\hline
\end{tabular}

$\mathrm{Cl}$ : confidence interval; MIC: minimum inhibitory concentration; N.a.: not applicable; ND: not determined.

${ }^{a}$ As susceptibility to colistin was not tested in 2007 , each isolate obtained in that year was tested for the presence of $m c r-1$.

In spite of this, prior to 2015 , the mechanism of resistance to colistin was only known to involve chromosomal mutations, and so its spread was expected to be limited to vertical transmission [6]. In 2015 however, the first plasmid-mediated colistin resistance involving the mrc-1 gene was discovered in China by Liu et al. [4]. Since, other reports detail retrospective detection of this gene in E. coli from animal origin. In Germany, the gene was found in three of the 129 whole-genome sequences of $E$. coli isolated from livestock since 2009 [7]. The mrc-1 positive strains originated from swine and were sampled in 2010 and 2011. The $\mathrm{mcr}$-1 gene was also detected in five $E$. coli isolates from chicken meat of European origin imported in Denmark in 2012, 2013 and 2014 [8]. In Belgium, 13 of 105 colistin-resistant $E$. coli isolates collected in 2011 and 2012 from piglets and bovine calves with diarrhoea were positive for $m c r-1$ [9]. Also, in France, extended-spectrum betalactamase (ESBL)-positive $E$. coli isolated from diarrhoeic bovine calves as early as 2005 were confirmed to be $m c r-1$ positive [10] as well as four Salmonella isolates from 2012 to 2013 collected within the French agricultural food sector [11]. A number of these findings implicated pathogenic strains, isolated in the context of event-based surveillance networks or programmes.

Prompted by these reports of mrc-1-mediated colistin resistance, we investigated the prevalence of $\mathrm{mcr}-1$ in non-pathogenic $E$. coli isolated through the official European surveillance programme on antimicrobial resistance in French livestock. This programme is designed to be comparable between Member States but its power to detect emergent resistance is likely to be limited. In fact, after three years of continuous monitoring, starting from an initial theoretical point of $0.1 \%$ of resistant isolates, this programme cannot detect any changes if the overall increase is lower than $2 \%$ per year [2]. The fact that $m c r-1$ emergence is detected through this surveillance programme supports the idea of a rapid spread of plasmid-mediated colistin resistance in French livestock.

The presence of co-resistances in strains harbouring the mcr-1 gene could have contributed to select and enhance the rapid dissemination of the plasmidmediated resistance to colistin jointly with antibiotic pressure by other antimicrobial use in food producing animals.

The dissemination of $m c r-1$ in French livestock, either in a pathogenic or healthy context, raises the question of colistin use in animals. Colistin use should be now revisited in a double perspective: first, in a veterinary medicine perspective, that might suddenly start to face treatment failures in animal digestive disorders such as colibacillosis or salmonellosis; and second, in a human medicine perspective, in order to maintain the efficacy of a last-resort therapeutic option to counteract multidrug-resistant bacterial infections [5].

\section{Acknowledgements}

This work was supported by the French Agency for Food, Environmental and Occupational Health \& Safety (ANSES) and funded by the French Ministry of Agriculture, Food and Forestry. Authors would like to thank Sophie A. Granier for her critical edition of this manuscript.

\section{Conflict of interest}

None declared.

\section{Authors' contributions}

APG designed the study, analysed and interpreted data, drafted and coordinated the manuscript elaboration, $M B$ analysed the data and contributed to the manuscript, $\mathrm{PH}$, $\mathrm{KD}, \mathrm{PL}, \mathrm{CP}$ produced phenotypic and molecular data, CS contributed to the manuscript, PS contributed to the manuscript and given scientific advice. 


\section{References}

1. European Commission. Directive 2003/99/EC of the European Parliament and of the Council of 17 November 2003 on the monitoring of zoonoses and zoonotic agents, amending Council Decision 90/424/EEC and repealing Council Directive 92/117/ EEC. Official Journal of the European Union. Luxembourg: Publications Office of the European Union. 12.12.2003: L $325 / 31$.

2. European Food Safety Authority. Technical specifications on the harmonised monitoring and reporting of antimicrobial resistance in Salmonella, Campylobacter and indicator Escherichia coli and Enterococcus spp. bacteria transmitted through food. EFSA Journal. 2012;10(6):2742. Available from: http://www.efsa.europa.eu/efsajournal

3. European Committee on Antimicrobial Susceptibility Testing (EUCAST). Växjö: EUCAST. Available from: http://www.eucast. org/

4. Liu Y-Y, Wang Y, Walsh TR, Yi L-X, Zhang R, Spencer J, et al. Emergence of plasmid-mediated colistin resistance mechanism MCR- 1 in animals and human beings in China: a microbiological and molecular biological study. Lancet Infect Dis. 2015. [Epub ahead of print]

5. Catry B, Cavaleri M, Baptiste K, Grave K, Grein K, Holm A, et al. Use of colistin-containing products within the European Union and European Economic Area (EU/EEA): development of resistance in animals and possible impact on human and animal health. Int J Antimicrob Agents. 2015;46(3):297-306. DOI: 10.1016/j.ijantimicag.2015.06.005

6. Lim LM, Ly N, Anderson D, Yang JC, Macander L, Jarkowski A, et al. Resurgence of colistin: a review of resistance, toxicity, pharmacodynamics, and dosing. Pharmacotherapy. 2010;30(12):1279-91. DOI: 10.1592/phc0.30.12.1279

7. RESET consortium, Falgenhauer L, Waezsada S-E, Yao Y, Imirzalioglu C, Käsbohrer A, Roesler U, et al. . Colistin resistance gene $\mathrm{mcr}-1$ in extended-spectrum $\beta$-lactamaseproducing and carbapenemase-producing $\mathrm{Gram}$-negative bacteria in Germany.Lancet Infect Dis. 2016. [Epub ahead of print] DOI: 10.1016/S1473-3099(16)00009-8

8. Hasman H, Hammerum AM, Hansen F, Hendriksen RS, Olesen $B$, Agersø $\mathrm{Y}$, et al. Detection of mcr-1 encoding plasmidmediated colistin-resistant Escherichia coli isolates from human bloodstream infection and imported chicken meat, Denmark 2015. Euro Surveill. 2015;20(49):30085. DOI: 10.2807/1560-7917.ES.2015.20.49.30085

9. Malhotra-Kumar S, Xavier BB, Das AJ, Lammens C, Butaye P, Goossens $\mathrm{H}$. Colistin resistance gene mcr-1 harboured on a multidrug resistant plasmid.Lancet Infect Dis. 2016. [Epub ahead of print] DOI: 10.1016/S1473-3099(16)00012-8

10. Haenni M, Poirel L, Kieffer N, Châtre P, Saras E, Métayer V, et al. Co-occurrence of extended spectrum $\beta$ lactamase and MCR1 encoding genes on plasmids. Lancet Infect Dis. 2016. [Epub ahead of print] DOI: 10.1016/S1473-3099(16)00007-4

11. Webb HE, Granier SA, Marault M, Millemann Y, den Bakker $\mathrm{HC}$, Nightingale KK, et al. Dissemination of the mcr-1 colistin resistance gene. Lancet Infect Dis. 2015. [Epub ahead of print]

\section{License and copyright}

This is an open-access article distributed under the terms of the Creative Commons Attribution (CC BY 4.0) Licence. You may share and adapt the material, but must give appropriate credit to the source, provide a link to the licence, and indicate if changes were made.

This article is copyright of the authors, 2016. 